\title{
The role of organizational culture in improvement of professional ethics in research organizations
}

\author{
Ali Baqi* and Reza Ghaffari Tabar
}

Accounting \& Management Department, Kashan Branch, Islamic Azad University, Kashan, Iran

\begin{tabular}{l}
\hline C H R O N I C L E \\
\hline Article history: \\
Received January 15, 2013 \\
Received in revised format \\
30 April 2013 \\
Accepted May 42013 \\
Available online \\
May 5 2013 \\
\hline Keywords: \\
Organizational culture \\
Professional ethics \\
Organization
\end{tabular}

\section{A B S T R A C T}

\begin{abstract}
Culture is the soul of an organization, which can cause advance or retrogress of the organization. This paper investigates the role of organizational culture on improvement and effectiveness of organizations. We identify and recognize the role of important components of organizational culture in effectiveness of professional ethics within organizations. The results show that there was a meaningful relationship between organizational interest and commitment, enhancement of stability and compatibility, teamwork moral, giving identity to the staff and the quality of professional ethics. The results obtained from the data analysis also indicate that organizational culture deeply affects the employees' behavior of an organization.
\end{abstract}

\section{Introduction}

Organizational culture is new term in management literature and it has received significant attentions (Martin, 1992). Harris and Ogbonna (2001) described the effect of top management leadership style in affecting the process of market orientation development. They began with a review of existing definitions of and perspectives on the content and components of market orientation and performed their survey into the barriers and processes of market orientation. According to Deshpande and Webster Jr (1989), contemporary work on marketing management was grounded in a structural functionalist but the field of organizational behavior from which such a perspective derives was developed a major thrust into theoretical modeling and empirical research on organizational culture (Hofstede, 1983; Peters \& Waterman, 2004).

Deshpande and Webster Jr (1989) studied the emerging literature on organizational culture, integrated it in a conceptual framework, and then developed a research agenda in marketing grounded in the

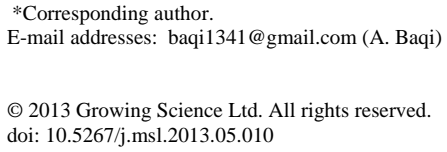


different cultural paradigms. Organization culture contains four main elements, which exist in various levels of awareness, as follow:

1- Basic assumptions in the deepest level of cultural knowledge,

2- Unconscious and absolute assumptions located on how to solve organizational problems,

3- Values within organizational commands and what staff should be justified towards them.

Organizational culture can create the background for four functions in the organization, which are as follow:

1- Giving identity: Organizational culture is a source and reference to identify sense of the staff. On this basis, the employees recognize their personalities based on the culture of the organization.

2- To form the staff behavior: the organization forms its behavior based on powerful culture and aids the members to find out their work environment.

3- Enhancement, stability and compatibility: Culture in terms of society is considered as a mortar, which can connect the organization components through a standard provision.

4- Making an internal commitment: Organizational culture helps employees create a sort of commitment and responsibility towards something, which is more than the individuals' benefits. According Kilmann et al. (1985), introduced five key features for understanding organizational culture and explained that the effect of organizational culture on performance and organizational effectiveness may be considered from three aspects:

1- Leadership: It means that culture is a way to meet organizational aims and leads the organization to reach or miss it (Trice, 1984).

2- Permeability of culture is created when all the employees of an organization are involved in its culture, accept it and perform it.

The power of culture indicates its effects on employees and the organizations and powerful culture are mostly capable of leadership and tact of senior management. Norms lead the members on how to act in special positions and they are normally some unwritten behavioral values. According to Robbins (2005), the ratio of culture within organization is the same as the ratio of personality to an individual. In addition, culture of each organization indicates its identity and the disjunction toward other organizations. Organizational culture is a part of internal environment of the organization, which is a combination of common commitments and values among the members and it helps employees do their duties under the current circumstance (Deal \& Kennedy, 2000; Kotter, 2008).

Organizational culture acts as a source for the organization abilities, on the other word, success and failure of the organizations significantly depend on their culture (Berson et al., 2005). Therefore, in order to improve professional ethics within organizations, organizational culture should be more accounted within organizations since culture is standing for the human perception of his/her residential environment and indicates his/her opinions and behavior (Schein, 2006).

Culture incorporates an ethical concept, which detects the boundary between true and false or good and bad for each group. Generally, culture influences the way of speculation and employees' behavior. If we admit that today's humans cannot live without their organizations and institutions, which include their fellowman, we should also admit that most part of their behaviors derived from these organizations. If the rules and regulations within organizations form the formal behavior of the staff, organizational culture will dictate the informal behavior of them (George et al., 2002).

Organizational culture helps us improve professional ethics within an organization. This study intends to provide a framework to determine how organizational culture could be accounted for an important factor in effectiveness and efficiency of creative professional performance in the organizations. Therefore, a proper work culture, which is well developed between management and staff, will lead to the strength of organizational commitment, improvement of a higher efficiency performance and 
finally, improvement of professional ethics in the organization. A considerable number of the scientists have confirmed the dissipation and difference in perspectives about the perceptions on organizational culture. Malmir et al. (2013) reviewed recent advances on leadership style and various aspects of organizational cultures completed during the past few years. Faradonbeh et al. (2013) proposed an empirical investigation to learn the relationship between ethical leadership and organization learning.

The proposed study designs a questionnaire based on Northouse's model (Northouse, 2012) and distributed it among all 108 managers in province of Charmahal-Bakhtiari located in west part of Iran and, using Pearson correlation, they examined various hypotheses. They reported that five components of ethical leadership including respect, serve, justice, honesty and socialization had positive and meaningful relationship with organizational learning. Aghadavood et al. (2013) investigated the relationship between the moral leadership style of mangers and organizational confidence of Shahre-Kord high school teachers. Their findings showed that the impact of moral leadership along with its parameters on the organizational confidence and its parameters were significant.

\section{The proposed model}

This paper investigates the role of organizational culture on improvement and effectiveness of organizations. We identify and recognize the role of important components of organizational culture in effectiveness of professional ethics within organizations. The study has been executed in province of Qom, located north part of capital city of Iran. Statistical populations of the study are religious research centers of Qom province and of 157 centers, and 8 centers were studied.

In this study to codify subjective literature, data were gathered using liberation references, and in order to study the role of organizational culture to improve professional ethics in organizations, data were collected using questionnaires. The author questionnaire was settled in two parts of repliers and main questions, which included 47 questions. The questionnaire justifiability was set in two parts: apparent and content.

The questionnaire stability equals to 93\% according to alpha-Cronbakh method. The questionnaire included hypothesis in which some questions were presented and then designed by Likert spectrum method. In order to analyze and obtain the results from the collected data, regarding to the study method, SPSS software was used to compare the average results of eight organizations of religious research centers in Qom province.

\section{The results}

Table.1 shows the distribution of repliers' opinions about organizational culture and total evaluation of professional ethics in religious research centers of Qom. Data show that more than half of the repliers (60\%) have evaluated the organizational culture as an average to high levels among the staff. (40\%) have evaluated it low and very low level, which is a significant percent and should be considered. Organizational culture variable has got from 1 to 5 scores. Average organizational culture is 2.6, i.e. more than half of the repliers have got scores more than the average.

Generally, in this study, organizational culture is considered as one the most important indicators of professional ethics, which is located in a relatively proper atmosphere according to the data obtained from table of organizational culture in religious research centers of Qom province. In the following, data about total of professional ethics show that most repliers of the population (56\%) have evaluated the professional ethics in religious research centers of Qom as high and very high level. (44\%) have evaluated it low, which is considerable as well. 
Professional ethics has got from 1 to 5 scores in religious centers. The average level of professional ethics obtained ( $2.58 \%$ ), i.e. more than half of the repliers have got a score more than the assumed average of 3. In general, professional ethics is the main purpose of this study, which was evaluated average to high by the repliers, according to the data obtained from the Table 1.

Table 1

Distribution of repliers' opinions about the professional ethics indicators in Qom religious research centers

\begin{tabular}{lccccccc}
\hline \multicolumn{1}{|l}{ Indicator } & $\begin{array}{c}\text { Very low } \\
\text { percentage }\end{array}$ & $\begin{array}{c}\text { Low } \\
\text { percentage }\end{array}$ & $\begin{array}{c}\text { High } \\
\text { percentage }\end{array}$ & $\begin{array}{c}\text { Very high } \\
\text { percentage }\end{array}$ & mean & $\begin{array}{c}\text { Standard } \\
\text { deviation }\end{array}$ & variance \\
\hline $\begin{array}{l}\text { Organizational culture } \\
\begin{array}{l}\text { Total evaluation of professional } \\
\text { ethics model }\end{array}\end{array}$ & 4 & 36 & 52 & 8 & 2.6 & 0.69 & 0.47 \\
\hline
\end{tabular}

Statistical results obtained from studying the relationship between organizational culture, organizational interest and commitment, morale and tolerance of the staff, enhancement of stability and adaptability, teamwork morale and identity of the staff as the independent variables and professional ethics quality as the dependent variable, in religious research centers of Qom province, are shown in Table 2.

\section{Table 2}

Results of correlation test between organizational culture, organizational interest and commitment

\begin{tabular}{llcc}
\hline Independent variable & Dependent variable & Correlation coefficient & Meaningfulness level \\
\hline Organizational culture & Professional ethics quality & 0.65 & 0.000 \\
Organizational interest and commitment & Professional ethics quality & 0.462 & 0.000 \\
Resistance and morale of staff & Professional ethics quality & 0.552 & 0.000 \\
Enhancement and stability of staff & Professional ethics quality & 0.499 & 0.000 \\
Team work morale & Professional ethics quality & 0.42 & 0.000 \\
Giving identity to the staff & Professional ethics quality & 0.441 & 0.000 \\
\hline
\end{tabular}

Results of the above correlation test between independent variable (organizational culture) and dependent variable (professional ethics quality) show that there was a significant relation and positive correlation between the two variables when the level of significance is $5 \%$. The obtained coefficient was 0.65 , which shows a high relationship between the correlations of the two variables. Therefore, the alternative hypothesis, $\mathrm{H}_{1}$, which says there is a meaningful relation between organizational culture and professional ethics quality in Qom religious centers, was confirmed.

Correlation test results between independent variables of organizational interest and commitment and the dependent variable, professional ethics quality, shows that there was a meaningful and positive correlation between these two variables in an error level of 0.05 . The coefficient obtained was 0.462 , which shows a high correlation between the two variables. Therefore, hypothesis $\mathrm{H}_{1}$, which says there is a meaningful relation between morale and tolerance of staff and professional ethics quality, was confirmed.

The results of the correlation test between the independent variable of enhancement of stability and compatibility and dependent variable of professional ethics quality show that there was a significant and meaningful correlation between the two variables when the level was 5\%. The obtained coefficient is 0.499 , which shows a high correlation between the two variables. Therefore, hypothesis $\mathrm{H}_{1}$, which says there was a meaningful correlation between enhancement of stability and adaptability and professional ethics quality was confirmed.

The results obtained from correlation between the independent variable of teamwork morale and dependent variable of professional ethics quality show that there was a meaningful and positive correlation between the two variables when the level of significance is $5 \%$. The obtained coefficient was 0.42 , which shows a high correlation between the two variables. Therefore, hypothesis $\mathrm{H}_{1}$, which 
says there is a meaningful relation between teamwork morale and professional ethics quality was confirmed.

The results obtained from the correlation between the independent variable of identity of the staff and dependent variable of professional quality show that there was a positive meaningful correlation between the two variables when the level of significance is $5 \%$. The obtained coefficient was 0.441 , which shows a middle correlation between the two variables. Therefore, hypothesis $\mathrm{H}_{1}$, which says there is a meaningful relation between identity of the staff and professional ethics quality, was confirmed.

\section{Conclusion}

Organizational culture as a set of common belief values influences on behavior and thoughts of research organizations members and can be concerned as a start point to move and act or a barrier to improve professional ethics. According to the findings of this study, a great level of organizational culture has been established and formed in religious research centers of Qom province. Repliers of the religious centers have had a good evaluation from them. They gave a score of 3 out of 5 to these centers, and imagined a proper atmosphere of organizational culture.

Regarding to these results and tests of the research hypotheses and relationships between dependent and independent variables, the strength of organizational commitment, increase of performance and productivity improvement and finally, organizational progress, will be occurred if a proper work culture is developed between management and staff. The results of correlation coefficient and determination between the variables from 0.42 to 0.65 show a high level of correlations. In addition, their strength meaningfulness of the hypothesis tests when the level of significance was 5\% implied confirmation of the main hypothesis and suggests the relationship between professional ethics quality, as a dependent variable, and the independent variables mentioned above. Detailed results and numbers of the findings and esting various hypotheses have been presented in research findings.

\section{References}

Aghadavood, S., Dehaghani, M., Dehkordi, L., Faradonbeh, M \& Sedeian, S. (2013). A study on relationship between ethical leadership and organizational trust between teachers and principals: A case study of high school employees in Shahre-Kord, Iran. Management Science Letters, 3(4), 1233-1238.

Berson, Y. A. I. R., Oreg, S. H. A. U. L., \& Dvir, T. A. L. Y. (2005). Organizational culture as a mediator of CEO values and organizational performance. In Academy of Management Proceedings (pp. 1-6).

Deal, T. E., \& Kennedy, A. A. (2000). Corporate cultures: The rites and rituals of corporate life. Basic Books.

Deshpande, R., \& Webster Jr, F. E. (1989). Organizational culture and marketing: defining the research agenda. The Journal of Marketing, 3-15.

Faradonbeh, M., Faradonbeh, F., Semiromi, M., Sedeian, S \& Rostami, A. (2013). A study on relationship between ethical leadership style and organizational learning based on Northouse model: A case study of governmental organizations in province of Charmahal-Bakhtiari in Iran. Management Science Letters , 3(5), 1415-1420.

George, J. M., Jones, G. R., \& Sharbrough, W. C. (2002). Understanding and managing organizational behavior. Upper Saddle River, NJ: Prentice Hall.

Harris, L. C., \& Ogbonna, E. (2001). Leadership style and market orientation: an empirical study. European Journal of Marketing, 35(5/6), 744-764.

Hofstede, G. (1983). The cultural relativity of organizational practices and theories. Journal of international business studies, 14(2), 75-89. 
Malmir, M., Esfahani, M \& Emami, M. (2013). An investigation on leadership styles in different cultures. Management Science Letters, 3(5), 1491-1496.

Martin, J. (1992). Cultures in organizations: Three perspectives. Oxford University Press.

Northouse, P. G. (2012). Leadership: Theory and practice. SAGE Publications, Incorporated.

Kilmann, R. H., Saxton, M. J., \& Serpa, R. (1985). Introduction: five key issues in understanding and changing culture. Gaining control of the corporate culture, 1-16.

Kotter, J. P. (2008). Corporate culture and performance. Free Press.

Peters, T. J., \& Waterman, R. H. (2004). In search of excellence: Lessons from America's best-run companies. Harper Business.

Robbins, S. P. (2005). Essentials of organizational behavior. Prentice Hall.

Schein, E. H. (2006). Organizational culture and leadership (Vol. 356). Jossey-bass.

Trice, H. M., \& Beyer, J. M. (1984). Studying organizational cultures through rites and ceremonials. Academy of management review, 9(4), 653-669. 